\title{
Özbek Türkçesi Dilbiliminde Çağrışım Sözlüğünü Oluşturmanın Kuramsal ve “Beşik" Kelimesi Örneğinde Uygulamalı Yöntemleri ${ }^{*}$
}

\author{
Zilola Khudaybergenova**
}

$0 \ddot{z}$

XXI. yüzy1lın dünya dilbiliminde insan faktörü, dil incelenmesinin ana konusu haline geldi. Bunun sonucunda "insan+kültür+dil" üçgenine dayanan yeni dilbilim dalları ortaya çıktı. Bununla beraber kültürel dilbilim, edim dilbilimi, ruhbilimsel dilbilim, bilişsel dilbilim, toplumsal dilbilim, çağrışım dilbilimi gibi dilbilim kolları doğmuş oldu. Bu dallar, ana dili konuşurunun kognitif, psikolojik, kültürel, ulusal ve sosyal özellikleri; toplumun ortak dilinin tarihi, milli gelenekleri, siyasi ve kültürel belirtileri yanı sıra söz konusu ülkenin coğrafi koşulları ile etkileşimini dikkate alarak hedef dili incelemektedirler. Çağrışım dilbilimi, ana dili konuşurlarının zihninde belirli kavramlarla alakalı ortaya çıkan çağrışımları inceler. Dolayısıyla, çağrışım sözlüklerinin yazılmasına gerek duyulmuştur. Yirminci yüzyılında yayımlanan birçok dilin çağrışım sözlükleri Özbek bilim insanlarının dikkatini çekti. Özbek Türkçesinin bir çağrışım sözlüğünün hazırlama çabalarının başlatılmasına neden oldu. Bu makalede çağrışım sözlüklerinin hazırlanması tarihi, çağrışım sözlüklerini yapmanın teorik ve pratik yöntemleri, Özbek Türkçesi çağrışım sözlüğünü oluşturmaya yönelik çalışmalar, çağrışımları inceleme ilkeleri, bu sözlüğün yapısı ele alınacaktır.

\section{Anahtar Kelimeler}

Özbek Türkçesi, Özbek Türkçesi çağrışım dilbilimi, çağrışım sözlükleri, çağrışım deneyimi yöntemi, çağrışım birimleri, çağrışım sözlüklerini oluşturma ilkeleri.

Geliş Tarihi: 26 Ocak 2019 - Kabul Tarihi: 19 Haziran 2019

Bu makaleyi şu şekilde kaynak gösterebilirsiniz:

Khudaybergenova, Zilola. "Özbek Türkçesi Dilbiliminde Çağrışım Sözlüğünü Oluşturmanın Kuramsal ve 'Beşik' Kelimesi Örneğinde Uygulamalı Yöntemleri.” bilig, no. 98, 2021, ss. 75-97.

** Prof.Dr., Bartın Üniversitesi, Edebiyat Fakültesi, Çağdaş Türk Lehçeleri ve Edebiyatları Bölümü Bartın/Türkiye

ORCID: 0000-0003-1021-3053

aloliz74@mail.ru, zkhudaybergenova@bartin.edu.tr 


\section{Giriş}

Dünya dilbiliminde geleneksel olarak üç paradigma olduğu itiraf edilir: XIX. yüzyılın dilbiliminde kıyasi-tarihi paradigma egemen olduğundan bu doğrultudaki araştırmalarda kıyasi-tarihi yönteme dayanılmıştır. XX. yüzyıl dilbilimi irdeleme merkezinde nesne, yani sözcük olduğu için dizgeli-yapısal paradigma meydana geldi. En sonunda, XXI. yüzyılda yeni dilbilimi stratejilerinin işlenmesi ve incelenmeler için obje değil insanın seçilmesi nedeniyle 'antroposentrik paradigma' ortaya çıktı. Özbek Türkçesi dilbiliminin bilimler arası sorunları araştırmaya başvurması, ilk olarak XX. yüzyılın 2. yarısında dünya dilbiliminde devrim yapan görüşlerin oluşmasına, yani önce yapısal dilbilimi prensiplerinin tercih edilmesine, XXI. yüzyılın başında bu saha yerine fonksiyonel dilbiliminin ağı basmasına ve 'antroposentrizm' ilkesinin hâkim olmaya başlamasına neden olmuştur.

$\mathrm{Bu}$ dönemde Özbek Türkçesi dilbilimi araştırmaları çerçevesinde 'homo eloquens' (konuşan insan), onun iletişimle ilgili amaçları, anlayışları, iletişim ortamı ve iletişim prensipleri incelemeye başlandı. Aynı zamanda Özbek Türkçesi dilbilimine ait araştırmalarda konuşarak iletişimin optimizasyonu sorunları, çözülmesi beklenen en önemli konulardan birine dönüştü. Sonuç olarak, Özbek Türkçesi dilbiliminin pragmatik dilbilimi, psikolojik dilbilimi, toplum dilbilimi gibi dalları meydana geldi ve kısa bir sürede bu yönde birçok bilimsel araştırmalar uygulandı. Özellikle, ruhbilimsel (psikolojik) dilbiliminin bir dalı olarak oluşan çağrışım dilbilimi teorisi için temel atıldı.

Son zamanlarda Özbek Türkçesi dilbiliminde de çağrışım dilbilimi ve Özbek Türkçesi çağrışım sözlügünü yaratmak üzere birçok bilimsel araştırmalar yapılmaktadır. Özellikle, Dr. Prof. Durdona Lutfullayeva önderliğindeki ekip tarafından Özbek Türkçesi çağrışım sözlüğünü oluşturmak çalışmaları yapılmaktadır. Bu ekip, Özbek Dili ve Edebiyatı Üniversitesi öğretim elemanları ve öğrencileri arasında 180 sözcügün çağrışımlarını anket yöntemiyle toplamış olup onların değerlendirmesini yapmaktadır (Lutfullayeva 5).

\section{Çağnışım Sözlüklerini Hazırlama Tarihçesi}

Geçen yüzyılda Özbek sözlükbilimi alanında amacı ve işlevine göre çeşitli sözlükler yayınlandı. Böyle sözlükler arasında 80 bin kelimeyi içeren 5 ciltlik Özbek Türkçesinin Açıklamalı Sözlüğü, Çăgdaş Özbek Türkçesi AktifSözcüklerinin Açıklamalı Sözlü̈̆̈̈ (Hojiyev vd.), Ş. Rahmatullayev’in üç ciltlik Özbek 
Türkçesinin Etimolojik Sözlü̈̆̈̈, E.Begmatov'un Özbek İsimlerinin Anlamı, Alpamiş Destaninın Açıklamalı Sözlüğü (Mirzayev vd.), N. Mahkamov, İ Ermatov'un Dilbilimi Terimlerinin Açıklamalı Sözlügü̈, N. Mahmudov, D. Hudaybergenova’nın Özbek Türkçesi Mecazlarının Açıklamalı Sözlüğü gibi sözlükleri sayabiliriz. Buna rağmen, Özbek sözlükbiliminde oluşturulması gereken birçok sözlük çeşitleri olduğunu da dile getirmeliyiz. Özellikle Özbek Türkçesinin Çağrışım Sözlüğünü düzenlemek de Özbek Sözlükbilimin gündemine gelmiştir.

Dünya dilbiliminde birinci çağrışım sözlüğü 1910 yılında Amerikalı bilim adamları H. G. Kent ve A. J. Rozanoff tarafından İngiliz dili verilerine dayanarak oluşturulmuştur (317-390). Bu sözlükte en çok kullanılan 100 dürtü kelime seçildiği 1000 kişinin denek olarak katıldığı çağrışım deneyiminin sonuçları yansımışıır ${ }^{1}$. Sonra İngiliz bilim adamları L. Postman, G. Keppel tarafından İngiliz, Fransız, Alman dillerindeki çağrışım normlarını içeren Çağrışım Sözcükleri Düzgüleri yayınlanmıştır. İlk çağrışım tesarusu G. Kiss önderliğinde ABD'nin Edinburgh Üniversitesi ruhbilimcileri tarafından oluşturmuştur (6).

Rus dili deneyleri verilerine dayanan ilk çağrışım sözlüğü 1977 yılında A. A. Leontev editörlüğünde yayınlandı. Bu sözlükte 200 sözcüğün yanıtları tespit edilmiştir. Rus dilinin çağrışım sözlüğü malzemeleri 1994-1998 yıllar arasında yayınlanan 6 kitapta ve 2002'de yayınlanan 2 ciltlik kitapta bir araya getirilmiştir (Russkiy Assotsiativnıy Slovar). Bununla birlikte Rus dilinin başka dillerle karşılaştırmalı çağrışım sözlükleri de hazırlandı (Titova, Ulyanov, Dimitryuk, Sanchez Puig vd., Slavyanskiy Assotsiativniy Slovar). Ruhbilimsel ve kognitif dilbilimine ait yayınlanan kaynaklarda da çağrışım dilbilimi, çağrışım sözlüğüne ilişkin kimi bilgiler beyan edildi (Volkov, Zalevskaya, Belyanin, Slıshkin, Karasik, Alefirenko, Popova, Sternin). Çağr1şım dilbilimin ana terimleri ve onun kavramlarının irdelenmesine ait birçok araştırma da yapıldı (Bolotnova, Goroshko, Abramov, Abramova).

Ama şimdiye dek Özbek Türkçesinde bu çeşit bir sözlük yayınlanmamıştır. Özbek Türkçesi' ana dili konuşurlarının dilbilimsel bilinci ve düşünüşü, ruhbilimsel görüş ürünü olan çağrışım ilişkisini kuran sözcükler, onların insan hafızasında birbirini hatırlatmasına neden olacak iç ve dış etkenler, çağrışım birimlerinin dilbilimsel, sosyo-dilbilimsel, ruhbilimsel-dilbilimsel, 
kültürel dilbilimsel, cinsiyetle ilgili özelliklerin Özbek Türkçesinde de detaylı araştırılması gerekmektedir. Bu amaçla tabii ki yığınsal kapsamda gerçekleştirilecek çağrışım deneyimi yöntemine dayanarak Özbek Türkçesinde birbirine çağrışımlı bağlantı kuran sözcükleri belirlemek, onları anlamsal alanlarda birleştirmek, hem niteliksel hem niceliksel tahlilini yapmak, sonuçta 'Özbek Çağrışım Sözlüğü 'nü yaratmak lazım. Bu tür sözlüğün oluşturulması, dünya dilbiliminde bağımsız bir paradigma olarak biçimlenen, Özbek dilbilimine yeni yeni girmeye başlayan çağrışım dilbilimin bilim dünyasına daha derin kök atıp ilgi göreceği şüphesizdir.

\section{Çağrışım Sözlüklerini Hazırlamanın Kuramsal ve Uygulamalı İlkeleri}

Çağrışım sözlükleri nasıl bir sözlüktür? Bu gibi sözlüklerin yaratılmasından amaç nedir? Çağrışım sözlükleri toplumun hangi tabakalarının işine yarar?

Çağrışım sözlükleri, ana dili konuşurlarının dış dünya hakkındaki görüşü, dilbilimsel düşüncesi ve hafızasına dayanılarak oluşturulacak yeni tip bir sözlüktür. Bunun gibi sözlüklerde sözlügün maddebaşını birbiriyle çağrışımlı bağlanan birimler alanı teşkil eder. Aynı zamanda, sözlükte verilmiş olan çağrışımlarda ana dili konuşurların dış dünya hakkındaki görüşleri, bakışları, bilimi, ruhu, gerçekliği olan ilişkisi, hayat deneyleri, fikir-düşünceleri, sorunları yansıdığı görülür. Bu yüzden böyle sözlükler sadece bilim adamları için değil, belki toplum için de önemli bilim ve veri tabanı işlevini yapar.

Rus dili çağrışımlı-sözlü düzeneği hazırlanırken, birçok çağrışım sözlüklerinin yazarı Yu. N. Karaulov onları şöyle sınıflandırmıştır: A. Ana dili konuşurların hafızasında dünya görüşü tablosunu canlandıracak dildışı bilimler. B. Çağrışım-sözlü düzenekte dilsel bilincin oluşması. C. Dilin dilbilimsel yapısı ve sözlük varlığı (Karaulov 194).

Yu. Karaulov’a göre, birinci gruba giren bilimler (A) dil dişı verileri taşımaktadır, çağrışım sözleri, tamlamaları, cümleleri, metin parçalarında ana dili konuşurlarının hayatları boyunca sürekli ilişkide bulunduğu, onları çevirmiş olan gerçeklikteki nesne ve olayları adlandırıcı ve onları betimleyici dil dışı veriler yansır. Onların arasında siyasî, içtimaî hayat, sanat, moda, Rus hayatının bölgesel özellikleri, millî karakter belirtileri, ulus ve dünya tarihi ile ilgili sabit fenomenler vardır. 
Karaulov, ikinci grup bilgilerini (B) iletişim bilimi diye adlandırmıştır. Ona göre, böyle bilimler ana dili konuşurlarının dilsel bilincini yansımaya yarar, çünkü söz konusu bilimler dil, ulusal kültür hakkındaki düşünme unsurlarını kapsar, yanıtları vesilesiyle Rus gerçekliğindeki olaylar, tipik durumlar, kavramlar değerlendirilir.

Sonuç olarak, çağrışımlı-sözlü düzeneğin üçüncü bölümü (C) ana dili konuşurlarının çoğu için bilinçsiz, düşünülmeyen bilimler olup, dil yapısının tüm düzeyleri - sesbilgisi, şekil bilgisi, sözdizimi, dilbilgisi, çeşitli üsluplara ilişkin (konuşma, resmi, yazınsal vb.) söz varlığına ait bilimlerdir.

Dolayısıyla, çağrışımlı-sözlü düzenekte sadece dilbilime değil, aynı zamanda insan ve toplum hayatıyla ilgili bilimler de yer alır.

Çağrışım sözlügünün başka sözlüklerden farkı hakkında biraz bahsetmek gerekir.

Çağrışım sözlükleri amacı, yapısı, geniş ölçekli olup çeşitli alanlara ait bilimleri kapsar ve deneysel verilere dayanır.

1. Çağrışım sözlüğü belli bir dilin söz varlığını incelemekle birlikte ana dili konuşurlarının kelime dağarcığı ve hafızası üzerine bilgi edinmek, onların dünya hakkındaki görüşleri ile bilgisinin dilde yansıması konusunu araştırmak ve dili normalleştirmeyi hedeflemektedir. Çağrışım sözlükleri ana dili konuşurlarının toplumsal, tarihsel hafızası içine giriş için fırsat yaratıcı bir sözlük sayılır.

2. Çağrışım sözlükleri, belli bir dönemin dilinin söz varlığını ve o dilin yapısı hakkındaki bütün bilgileri içermektedir. Söz konusu sözlükler dili betimleyici "basit örnekli bilgi" değil; o, dil ve insan, dil ve toplum, dil ve ruh, dil ve kültür, dil ve ilim, dil ve teknoloji ilişkileri hakkında görüş oluşturucu, ana dili konuşurlarının dış dünya hakkındaki bilişsel bilimi, ruhbilimsel görüşü, gerçeklikle münasebetini gösterici dilsel kaynak sayılır.

3. Çağrışım sözlükleri, ilk önce dilsel bilinçte birbiriyle çağrışımlı ilişkili, cümle yapısı için hazır bilgiler işlevini üstlenen çağrışım birimleri için veri tabanıdır. Bununla birlikte böyle sözlükler vesilesiyle çağrışım birimlerinin anlamsal, dilbilimsel, biçemsel, türevsel, pragmatik, kültürel, cinsiyet özellikleri, kullanım frekansı hakkında bilgi edinmek mümkündür. Çağrışım 
sözlüklerinde, bilhassa diğer dilsel sözlüklerde tespit edilmeyen ulusal bilincin özgün nitelikleri yer alır.

Çağrışım sözlüklerinde insan hafızasında birbirini hatırlatıcı birimler alanı verilir. Bu alan terkibinde dil sahipleri tarafindan oluşturulan çeşitli çağrışımlar (çoğunlukla bu işlevde eşanlamlı, zıt anlamlı kelimeler, dürtü kelimeden türetilen sözcükler, deyimler ve atasözleri) yer alır. N. Karauylov'un tespit ettiğine göre çağrışım sözlüğü, bizim için biraz değişik olarak ne roman ya da gazete yazısındaki gibi bütün bir metin görünüşünde- ne dil bilgisel ya da açıklamalı sözlüklerde olduğu gibi dizgeli ayrıntı- cümleler olup cümle yapmak için gereken malzemeler olarak kullanıcı tamlamalar ya da kelime öbekleri görünümünde tecessüm eder' (191).

Çağrışım sözlüklerinin yapısı başka sözlük çeşitlerinden kesinlikle farklıdır. Çağrışım sözlüklerinde sözcüklerin anlamı, yapısı, dil bilgisel şekilleri ya da imlası hakkında bilgi verilmez. Söz konusu sözlüklerde çağrışım alanı birimleri, dürtü söz ve 'assosiyatlar' (tepki yanıtları) alfabe sırasına göre dizilir. Yerleştirme tertibi şöyledir: önce dürtü kelime yazılır, onun karşısına yanıt kelimeler kullanım frekansının düşmesine göre kaydedilir. Yanıtların kullanım frekansı ayraç içinde belirtilir. Tepki yanıtlar için aşağıdaki niceliksel bilgiler belirtilir: 1. 'assosiyat', yanıt tepkilerinin toplam sayısı. 2. Çeşitli yanıtlar sayısı. 3. Tek yanıtlar sayısı. 4. Yanıtlanmayan durumlar sayısı. Dürtü kelimelerin eşanlamlı, zıt anlamlı sıraları, ondan türemiş olan kelimelerin ayrıca belirtilmesi mümkündür.

Çağrışım sözlüğü ruhbilimsel dilbiliminde geniş ölçüde uygulanan yığınsal çağrışım deneyimi yöntemi sonuçlarına göre düzenlenir.

Çağrışım sözlükleri dilbilim ve bu gibi insan fenomeni sorunlarıyla ilgilenen disiplinler (bilişsel bilim, ruhbilim, edebiyat bilimi, halk bilimi (folklor), toplumbilim, siyaset bilimi, kültür bilimi, sanat bilimi, din bilimleri, tarih bilimi disiplinleri) için hangi bulguları sunar?

Çağrışım sözlükleri ilk önce kuramsal dilbilimin, sözcükbilimi, anlambilimi, dilbilgisi alanları için önemli bir veri tabanıdır. Bununla birlikte, böyle sözlükler dilbilimin ruhbilimsel dilbilim, bilişsel dilbilim, kültürel dilbilim, edim bilim (pragmatik dilbilimi), toplumsal dilbilim, budun dilbilim gibi birçok alanlarda gerçekleştirilecek olan araştırmalar için tahlil malzemesi olarak önemlidir. 
Örneğin, çağrışım sözlükleri belli bir dönemde kişilerin toplumsal hayatında gerçekleşen tarihsel olaylar hakkında da bilgi verir. Çağrışım deneyinde 'urush' (savaş) sözcüğü ile dile getirilen 'qon to 'kilishi' (kan dökmeyi): 'ocharchilik' (açlık), 'azob-uqubat' (sefalet), 'yetimlik' (öksüzlük), 'qayg'u-iztirob’ (üzüntü) yanıtları belli bir dönemde meydana gelen vakanın korkunç sonuçları deneğin hafızasında canlandırır. Çağrışım sözlükleri, milli kültüre ait olan bilgileri yansıtan milli bilinç inikâsı sayılır. Sözlük okurunun gözü önünde halk kültürünün örnekleri tezahür eder, ana dili konuşurunun milli-kültürel değerlerle münasebeti hakkında bilgiyi elde eder. Örneğin, deney sonucunda 'alla' (ninni) sözcügü için kaydedilen 'sabr' (sabır), 'fidoiylik' (fedakarlık), 'baxt' (mutluluk), 'shukrona' (tevekkül), 'so'z sehri' (sözün tesiri), 'baxtli hayat' (mutlu hayat), 'baxtli oila' (mutlu aile), 'qaynoq mehr nafasi' (şefkat nefesi), 'mehr nuri' (iyilik ışı̆̆ı), 'shifobaxsh' (tedavi edici) yanıtları ana dili konuşurlarının bu kutsal milli-kültürel değere olan pozitif bakışının ifade edildiği görülür. Çağrışımlar alanındaki ulusal-kültürel belirtisine göre fark edici 'verbal birimler' (kelimleler, kelime öbekleri, cümleler) kültür bilimi için mühim kaynak işlevini görür.

Çağrışım sözlüklerinde toplanan bilgileri iki gruba ayırabiliriz:

1. Dilsel bilgiler.

2. Dil dışı bilgiler.

Dilsel bilgiler. Sözlükte 'dürtü sözcük - yanıt tepki' ilişkisini irdelemek yoluyla sözcüklere has olan dilbilimsel nitelikler hakkında sonuç çıkarmak mümkündür. Kimi bilim adamları yanıt tepkilerin ancak dilbilimsel özelliklerini analiz etmeyi tercih ederler. G. A. Martinoviç 'assosiyat'ları dilbilim, runbilimsel dilbilim ve psikoloji açılarından araştırmak gerektiğini vurgular. Onun, bereza (huş ağacı) sözcüğünün yanıt tepkilerini şekil ve dil bilgisel açıdan şu şekilde tasnif ettiği görülür: 1) cümle şeklindeki yanıtlar; 2) yüklem şeklindeki yanıtlar; 3) kelime grubu şeklindeki yanıtlar; 2) kelime formu şeklindeki yanıtlar (Martinoviç).

D. Lutfullayeva’nın düşüncesine göre, yanıtları yalnızca şekil ve dilbilgisi açısından incelemek onların dil bilgisel nitelikleri hakkında detaylı hülasa etmek için yeterli olmaz. Bu durumda tepki yanıtların sözcük-anlamsal, türevsel, akustik, biçemsel ve başka özelliklerini belirleme imkânsız olacaktır. 
D. Lutfullayeva önderliğinde gerçekleştirilen deneyimlere göre 'dürtü kelime - tepki yanıt' ilişkisi dolayısıyla ortaya çıkacak çağrışım bağlantılı sözcüklere özgü olan aşağıdaki dil bilgisel özellikleri incelemenin de hedeflenmesi lazımdır:

1. Sözcüklerin çağrışım alanı: terkibi ve onun istatistik tahlili.

2. Çağrışım alanı birimlerinin sözcük-anlamsal özellikleri:

a) Dürtü sözcüğün anlamını ifade edici çağrışım birimleri;

b) Dürtü sözcüğün yan anlamlarını gerçekleştirici çağrışım birimleri;

c) Dürtü sözcügün mecazlı anlamlarını bildirici çağrışım birimleri;

d) Dürtü sözcügün sözcük-anlamsal paradigmalarını (eşanlamları, zıt anlamları, sesteşleri vb.) oluşturucu çağrışım birimleri.

3. Çağ rışım alan birimlerinin dil bilgisel nitelikleri:

a) Dürtü sözcüğün morfolojik şekillerini gerçekleştiren çağrışımlar;

b) Çağrışım birimlerinin morfolojik yapısı;

c) Çağrışım birimlerinin sözdizimi bakımından yapısı.

4. Çağrışım alan birimlerinin ahenk-akustik nitelikleri:

a) Dürtü sözcüğün fonetik şekilleri;

b) Çağrışım birimlerinin ahenk-akustik özellikleri.

5. Çağrışım alan birimlerinin türevsel özellikleri:

a) Dürtü sözcükten türemiş çağrışımlar;

b) Çağrışım birimlerinin türevsel bünyesi.

6. Çağrışım alan birimlerinin biçemsel nitelikleri:

a) Dürtü sözcüğün biçemsel değişimleri;

b) Çağrışım birimlerinin biçemsel belirtisi;

7. Çağrışım alan birimlerinin pragmatik nitelikleri:

a) Çağrışım birimlerinin metin açısından özelliği;

b) Çağrışım birimlerinin değerlendirme anlam özelliğinin ifadesi;

c) Çağrışım birimlerinin gösterme niteliği. 
8. Çağrışım alan birimlerinin cinsiyet nitelikleri.

9. Çağrışım alan birimlerinin kültürel nitelikleri:

10. Çağrışım alan birimlerinin içtimaî belirtisi (Lutfullayeva 104-105).

Dil dışı bilgiler. Çağrışım sözlükleri dil hariç insan ve toplum hayatiyle ilgili çeşitli bilimleri içerir. Yu. Karaulov Rus dili çağrışım sözlüğünde derlenen dil dışı bilgileri şöyle sınıflandırmıştır:

1. Adlar (kişi adları), yer adları, astronomik cisimler adları, ulus adları, kurum ve kuruluş adları, maddi ürünlerin sembolleri.

2. Kayıt, slogan ve reklamlar.

3. Toplum hayatı, siyaset, ekonomi, uygarlığın mühim özellikleriyle ilgili bilgiler.

4. Bilimsel bilgi.

5. Sanat ve kültüre ait malzemeler.

6. Gerçekliğin mecazlarla anlatılışı.

7. Deyimlerin dünya görünümü birimi olarak kullanılışı.

8. Tepki yanıtlarda anlatımsallık ve illüstrasyon.

9. Jest, yüz ifadeleri ve ahenk.

10. Genel kurallara dönüşen söyleyişler (geçinme kuralları, görüşler, düşünceler).

11. Kültürel tipik durumları yansıtıcı çerçeveler (Karaulov 195-199).

D. Lutfullayeva'nın tespit ettiğine göre, çağrışım sözlüklerinde 'dürtü sözcük - tepki yanıt' ilişkisine göre belirlenecek dil dışı bilgiler alanlara göre aşağıdaki gibi tasnif edilmiştir:

1. Bilişsel bilime ait bilgiler (ana dili konuşurlarının gerçeklik hakkındaki bilişsel bilgiler)

2. Psikolojiye ait bilgiler (ana dili konuşurlarının kişisel özellikleri: yaş, ruh, dünya görüşü, gerçekliğe münasebeti)

3. Kültürel alana ilişkin bilgiler

4. Dini alana özgü bilgiler

5. İctimai-siyasi alana ilişik bilgiler 
6. Ekonomiye ait bilgiler

7. Toplum tarihine ilişkin bilgiler

8. Sanat alanına ait bilgiler

9. Sporla ilgili bilgiler

10. Tipla ilgili bilgiler

11. Eğitime ait bilgiler

12. Teknolojiye ilişkin bilgiler (Lutfullayeva 106).

Dolayısıyla çağrışım sözlükleri, geniş kapsamlı yeni tip sözlüklerdir. Bu çeşit sözlükler insan fenomeni ile ilgili sorunları inceleyici birçok disiplinler için değerli veri tabanıdır.

\section{Özbek Çağrışım Sözlüğünü̈n Hazırlanması İçin Uygulamalar}

Çağrışım birimlerinin özünü daha iyi anlamak için Özbek Türkçesinin en çok kullanılan 180 sözcük örneğinde özgür çağrışım anketi gerçekleştirildi. Çağrışım anketi 2016-2017’lerde Alişir Nevai Taşkent Devlet Özbek Türkçesi ve Edebiyatı Üniversitesi Özbek Türkçesi ve Edebiyatını Okutma Fakültesi 3. sınıf öğrencileri ve öğretim görevlileri arasında yapıldı. Ankete 48 kişi katıldı. Sonuçta Özbek Türkçesi hakkında çeşitli çağrışımlar derlendi. Anket katılımcılarına dürtü kelimeler üzerine hafızalarında canlanan çağrışımları sınırsız sayıda kaydetme hakkı ve her bir dürtü sözcük çağrışımlarını yazmak için 3 dakika zaman verildi.

'Beshik' (beşik) sözcüğünün çağrışım alanı birimlerinin dilbilimsel betimi (dil bilgisel bilimler) ${ }^{2}$.

1. Beşik sözcüğünün çağrışım alanı aşağıdaki çağrışım birimlerinden teşekkül etti:

Beşik; chaqaloq (bebek) 8; alla (ninni), beshik to'yi (beşik kutlaması), ona (anne) 7; sumak (beşik parçası) 5; ko'zmunchoq (nazarboncuğu), tuvak (beşik parçası) 4; beshik asbob (beşik eşyaları), beshik bolasi (beşik çocuğu), beshik yopqich (beşik örtüsü), beshikka solish (beşiğe yerleştirme), buvi (dede), urf-odat (gelenek), farzand (çocuk), xursandchilik (kıvanç), bedorlik (uykusuzluk), bezaklar (süsler), belanchak (asılacak beşik çeşidi), belash (çocuğu beşiğe yerleştirerek bağlama), beshik anjomları (beşik eşya- 
ları), beshikka belash (beşiğe beleme), beshikketti (beşik kertmesi), beshik tebratish (beşik sallama), bolani beshikka solish (çocuğu beşiğe yerleştirme), yostiq (yastık), yostiqcha (küçük yastık), yig'i (ağlama), kelin (gelin), ko'rpacha (minder), qalampir (bebeğin oynaması için ipe dizilmiş karanfil), qo y so yish (koyun kesme), marosim (tören), momo (ağızlarda nine), ovutish (sakinleştirme, yatıştırma), ona allasi (anne ninnisi), orzu-umid (arzu, umut), pul (para), sut (süt), tilaklar (dilekler), tog'ora (düğünlerde misafirlere ikram edilen yemekler), to'y (düğün), to shakcha (küçük minder), tuproq surtish (toprak sürtme), xushkayfiyat (havasında olmak), cho'miltirish (banyo yaptırmak), qo'lbog' (kol bağı), hunarmandlar (ustalar) 2; 'Alla aytay, jonim bolam, orom olgin, alla, Onajoning jonidirsan, qo'zichog 'im, alla' (ninni parçası), 'Alpomish' dostonida Barchinoy va Hakimbek beshikketti qilingan' ('Alpamiş' destanında Barçinay ve Hakimbey bebekken beşik kertmesi olmuşlar), kadın, kadınlar, alerji, 'Ayam yoshligida tomdam beshik olib tushaman deb, uni tomdan tashlab sindirib qo'ygan ekanlar' (Annem gençliğinde çatıdan beşik alacağım derken, onu çatıdan düşürüp kırmış), ayajonımning ikki beshik orasida tunlari bilan alla aytib chiqqanlari (anneciğimin iki tane beşik ortasında gece boyunca ninne söylemesi), baxt (mutluluk), bezatilgan (süslenmiş), 'Beshik milliy-madaniy meros' (Beşik kültürel miras), 'Beşik toldan tayyorlanadi' (Beşik söğütten yapılır), 'Beshikdan qabrgacha ilm izla' (Beşikten mezara dek ilim ara - atasözü), 'Beshikning oyog'i yarim oy şaklida bo 'lib, u bolanining bir xil orom olishini ta’minlaydi' (Beşiğin ayağı yarım ay şeklinde olup, o çocuğun bir durumda dinlenmesini sağlar), 'Bolanining qo'l-oyoqları bo'lanadi' (Çocuğun elleri-ayakları bağlanır), beshigini tebratmoq (beşiğini sallamak), beshik ranglari (beşik renkleri), beshik tebratish (beşik sallamak), beshikchi (beşik yapan/satan), beshik yasovchi hunarmandlar (beşik yapıcı ustalar), beshikka belangan bola (beşiğe belenen çocuk), beshikka solish marosimi (çocuğu beşiğe beleme töreni), beshikni bezatish (beşiği süsleme), beshikni tuzatish (beşiği tamir etme), beshiksoz (beşik yapan), beshikso poq (beşikte çok yattığından düz kafalılık), beshikning bir maromda tebranishi (beşiğin aynı hızlıkta sallanması), beshiktervatar (peygamber sopası), bog ich (şerit gibi şey), bozorda sotish (pazarda satma), bola (çocuk), bola yotadigan joy (çocuğun yatacağı yer), bolalik (çocukluk), bolanı uxlatuvchi moslama (çocuğu uyutucu gereç), bolaning uxlab qolishi (çocuğun uyuyup kalması), bolaning qo'l-oyog 'ini bog'lash 
(çocuğu kundak yapma), bolaning mashinasi (çocuğun arabası), bolaning orom olishi va tinchlanishi (çocuğun sakinleşmesi ve dinlenmesi), bolaning tinch uxlashi (çocuğun sakin uyuması), buvilarimiz (ninelerimiz), vatan (doğum yeri), “Gigienik toza materiallardan tayyorlangan' (hijenik, sıhhi malzemelerden yapılmış), go'dak (bebek), go'sht (et), daraxt (ağaç), yopinchiq (örtü), yoshligimiz (gençliğimiz), yog'och (tahta), Jahongir Mirzaaliyev (ad, soyad), juda qulay (çok kullanışlı), juda foydali (sağlık için çok fayda1), zavq-shavq (zevk, eğlence), yig'layotgan bola (ağlayan çocuk), ip (ip), karnay-surnay sadolari (Özbek ulusal üflemeli çalgıların sesleri), kuy (müzik), kuyov (damat), kulgu (gülüş/tebessüm), ko'rmana (görümlük/bebeği ilk görüldüğünde verilecek para veya hediye), mehr-oqibat (sevgi, yardım), maktabga borishi kerak bo'lgan qizchaning beshikka yotib olishi (okula gidecek olan küçük kızın beşiğe yatması), mahalla (mahalle), mevali daraxt (meyveli ağaç), mehmonlar (konuklar), milliy marosim (ulusal tören), milliylik (milliyet), nabira (torun), namlik (rutubet), non (ekmek), ovqat (yemek), oyoqbog'(ayak bağı), oyoq-qo'llarning tog'ri bo'lishi (ayak-ellerin düzgün olması), oyijonim (anneciğim), oila (aile), ona-bola (anne-çocuk), onaning bolasini uxlatishi (annenin çocuğu uyutması), opa (büyük kızkardeş), opoqijonlar (büyük yaşlı kadınlara), orzu qilish (ummak), ota-onalarning shod-u xurramligi (ebeveynlerin kıvancı), parhez (perhiz/diyet), pichoq qo'yish marosimi (bıçak koyma töreni), san'at (sanat), sarpo qilish (dügü̈nlerde hediye edilen elbiseler takımı), singlim (küçük kızkardeşim), singliming chaqoloqlik davri (küçük kızkardeşimin bebeklik dönemi), soch (saç), suv (su), tabriklar (kutlamalar), tagi quruq (altı kuru), tandir (taom) (tandir - yemek çeşidi), taxta (tahta), tikuvchi (terzi), tiniqib uxlash (rahat uyumak), tirnoq (tırnak), 'Tol yoki tut daraxtidan tayyorlanadi' (Söğüt ya da dut ağacından yapılır), 'Tut va boshqa daraxtlarning yog'ochidan tayyorlanadi' (Dut ve diğer ağaçların tahtalarından yapılır), to 'kin dasturxon (güzel yemekler koyulmuş sofra), tun (gece), tong'ich farzand (birinci çocuk), tunlari beshikka suyangan kelin (geceleri beşiğe dayanmış gelin), uskuna (gereç), usta (usta), uxlatish (uyutma), farzandini uxlataman deb nogoh o'zi ham beshik quchib uxlab qolgan ona (çocuğunu uyutacağım diye kendinden geçmiş beşik kucaklayarak uyumuş kalmış anne), xayollar ummoniga g'arq bolish (hayal denizine dalma), halinchak (beşik - ağızda), chaqoloq yig isi (çocuk ağlaması), chaqoloqqa orom beruvchi moslama (çocuğu sakinleşti- 
rici malzeme), chaqoloqlarga mo'ljallangan tebranma belanchak (bebekler için yapılan sallanma beşik), chaqoloqlarni belaydigan maxsus moslama (bebeklerin belendiği özel gereç), chaqoloqlarning orom oladigan go'shasi (bebeklerin dinlendiği yeri), chaqoloqni belash (bebeği beleme), chaqoloqni tebratib uxlatish uchun moslama (bebeği sallayarak uyutmak için gereç), chaqoloqning kulib turishi (bebeğin gülümsemesi), chelak (kova), chilla (bebeğin kırkı), shirin choy (şekerli çay), shifokorlar (doktorlar), shukrona (müteşekkir), ena (ağızlarda anne), eng baxtiyor davr (en mutlu dönem), erkalanish (şımartma), ehtiyotkorlik (ihtiyat/tedbirlilik), yaqinlar (yakınlar), yangi tug ilgan chaqoloq (yeni dünyaya gelmiş olan bebek), yaxshi niyat (iyi niyet), 'O'zbek ayoli bir qo'li bilan beshikni, bir qo'li bilan dunyoni tebratadi' (Özbek kadını bir eliyle beşiği, öteki eliyle dünyayı sallar), o'zbek beshikleri (Özbek beşikleri), o'zbek xalqiga xos (Özbek ulusuna has), O'zbekiston (Özbekistan), uy (ev), o'yinchoqlar (oyuncaklar), o'ymakor naqshlar (oyma nakışlar), o'rmon (orman), qadriyat (değer), 'Qo'l mehnati yordamida tayyorlanadi' (El emeğiyle yapılır/el yapımı), 'Ona yurting oltin beshiging' (Ana yurdun, altın beşiğin), qaynonam (kaynanam/kayınvalidem), qaychi (makas), qalampirmunchoq (çocuğun oynamı ve sivrisinek gibi haşeratı uzak tutmak için karanfil baharatının ipe dizilmiş şekli), qand sochish (şeker saçma), qarindoshlar (akrabalar), qorakuya (kurum), quvonch ko'z yoshlari (sevinç/kıvanç gözyaşları), qulay va havfsiz (rahat ve korkusuz), qulaylik (kolaylık), qo'shni xalqlar (komşu uluslar), g'ichirlagan ovoz (gıcırdayan ses), 'Hali hamon ko'z oldimda' (hâlâ şimdi göz önümde şarkı parçası), havas (heves/istek), 'Hunarmandlar uni mashaqqatli mehnat bilan yasaydilar' (Zanaatçlar onu emek vererek yapıyorlar), hunarmandchilik (zanaat).

$273+122+151+0(273$ - toplam çağrışımlar sayısı, 122 - tekrarlanan çağrışımlar sayısı, 151 -tek çağrışımlar sayısı, yanıtlanmayan -o).

2. Beşik sözcüğü çağrışım alanı terkibi. İşbu alanda aktif sözcükler, çok sayıda kelime grubu, basit ve birleşik cümleler mevcuttur. Bununla birlikte, eskimiş sözcükler, ağız ve şiveye ait kelimeler, deyimler ve atasözleri de kaydedilmiştir.

3. Beşik sözcügünün istatistik tahlili: Ankete 22 denek katılmış, onlar 281 tane çağrışım yazmıştır. Bunlardan 48 çağrışım çeşitli şekillerde 2 ila 8 ara- 
sında bir sayıda tekrar edilmiştir. Tekrar kullanılan toplam çağrışımlar 122 tanedir. En çok 2 defa kullanılan çağrışımlar 64 tane olup (22:7\%), onlara klişe çağrışım diyebiliriz. Yinelenmeyen çeşitli çağrışımlar sayısı $151(54,5 \%)$.

4. Anket tahlilleri şunu göstermektedir ki, anket katılımcılarının çoğunda beşik sözcügüu, ilk önce, kültürel değer olarak görülmüştür. Ana dili konuşurları için beşik kelimesi çocuğu uyutmak için kullanılan gereç olmakla birlikte, Özbek halkının çocuğu beşiğe yatırma töreni, birinci çocuğu dünyaya getirdiğinde düzenlenecek olan beşik kutlamasını hatırlatmıştır.

5. Beşik sözcüğü çağrışım alanının sözcük-anlamsal tahlili.

“Özbek Türkçesinin Açıklamalı Sözlüğü”nde 'beshik' kelimesinin aşağıdaki anlamları verilmiştir:

1. Bebeği bağlayarak ve sallayarak uyutmak için sögüt ya dut ağacından yapılmış, yarım dairesel özel gereç, sallanma beşik.

2. (mecaz) Birer nesnenin, olayın dünyaya geldiği yeri, mekânı, kaynağı (Özbek Türkçesinin Açıklamalı 246). Çağrışımlar tahlili beşik sözcüğünün birinci ve mecaz anlamını dile getirildiğini göstermektedir.

Beşik kelimesinin çağrışım alanı birimlerinin dil bilgisel çözümlemesinden belli olur ki, morfolojik açıdan ad (bolalik (çocukluk), kulgu (gülüş), mahalla (mahalle), sıfat (juda qulay “çok kullanışlı”), juda foydali (çok faydalı), fiil (ovutish "sakinleştirme, yatıştırma”), cho'miltirish (banyo yaptırmak), belash (çocuğu beşiğe beleme) kullanılmıştır. Çağrışımlarım söz dizimi bakımından özelliğine bakıldığında, tamlamalar (beshik to yi "beşik kutlaması”), beshik anjomları (beşik eşyaları), ona allasi (anne ninnisi) ve cümleler ('Beshik milliy-madaniy meros' (Beşik ulusal-kültürel miras), Beşik toldan tayyorlanadi (Beşik sögütten yapılır), Beshikdan qabrgacha ilm izla (Beşikten mezara dek ilim ara [atasözü]) yazıldığı görülür . Beşik kelimesinin çağrışımlarında ahenk-akustik değişimlere uğramış olanlarına rast gelinmedi.

Bilişsel bilime ait bilimler. Beşiğin neden yapıldığı (söğüt veya dut ağacı), kimler tarafindan yapıldığı (zanaatçı), görünümünün nasıl, ne için kullanıldığına ait verilerde ana dili konuşurunun 'beshik' hakkındaki bilişsel bilgileri ifade etmiştir. 
Örneğin: beşiğin yapısı ve yapımına ait bilimler: sumak (beşik parçası), beshik asbob (beşik eşyaları), beshik yopqich (beşik örtüsü), ko'zmunchoq (nazar boncuğu), tuvak (beşik parçası), Beşik toldan tayyorlanadi (Beşik söğütten yapılır), Beshikning oyog'i yarim oy şaklida bo'lib, u bolanining bir xil orom olishini tảminlaydi (Beşiğin ayağı yarım ay şeklinde olup o çocuğun bir durumda dinlenmesini sağlar), beshik yasovchi hunarmandlar (beşik yapıcı ustalar), beshikni tuzatish (beşiği tamir etme), beshiksoz (beşik yapan), daraxt (ağaç), yog'och (tahta), yopinchiq (örtü), taxta (tahta), Tol yoki tut daraxtidan tayyorlanadi (Söğüt ya da dut ağacından yapılır), Tut va boshqa daraxtlarning yog'ochidan tayyorlanadi (Dut ve diğer ağaçların tahtalarından yapilır), Qo'l mehnati yordamida tayyorlanadi (El emeğiyle yapılır), Hunarmandlar uni mashaqqatli mehnat bilan yasaydilar (Zanaatçılar onu emek vererek yaparlar), hunarmandchilik (zanaat).

\section{Beşiğin kullanım amacına ilişkin bilgiler:}

belash (çocuğu beşiğe beleme), beshik anjomları (beşik eşyaları), beshikka belash (çocuğu beşiğe beleme), 'Bolanining qo'l-oyoqları bo'lanadi' (Çocuğun elleri-ayakları bağlanır), beshigini tebratmoq (beşiğini sallamak), beshikka belangan bola (beşiğe belenen çocuk), beshikka solish marosimi (çocuğu beşiğe beleme töreni), bolanı uxlatuvchi moslama (çocuğu uyutucu gereç), bolaning orom olishi va tinchlanishi (çocuğun sakinleşmesi ve dinlenmesi), bolaning tinch uxlashi (çocuğun sakin uyuması), oyoq-qo'llarning tog'ri bo'lishi (ayak-ellerin düzgün olması), ovutish (sakinleştirme, yatıştıma), tagi quruq (altı kuru).

Rubbilimine ait bilimler. 'beshik' dürtü kelimesinden ana dili konuşurlarının psikolojik durumu, ruhu, gerçekliğe ilişkisinden kaynaklanan çağrışımlar aşağıdaki verilmiştir: xursandchilik (kıvanç), bedorlik (uykusuzluk), yig'i (ağlama), ovutish (sakinleştirme, yatıştıma), orzu-umid (arzu, umut), xushkayfiyat (havasında olma), baxt (mutluluk), zavq-shavq (zevk, eğlence), yig layotgan bola (ağlayan çocuk), kulgu (gülüş/gülümseme), mehr-oqibat (şefkat, yardım), orzu qilish (ummak), ota-onalarning shod-u xurramligi (ebeveynlerin kıvanc1), xayollar ummoniga garq bolish (hayaller denizine dalma), ehtiyotkorlik (ihtiyat/tedbirlilik), yaxshi niyat (iyi niyet) vb. Görüldüğü gibi, dürtü kelime çocuğun dünyaya gelmesiyle insanların kalbinde doğmuş olan kıvanç, mutluluk, çocukla ilgili duyular, çocuk bakmaktan 
doğan hisleri ifade etmektedir.

Kültürel alana ait bilimler ise aşağıdaki çağrışımlarda ifade edilmiştir: beshik to'yi (beşik kutlaması), tuproq surtish (toprak sürme), 'Beshik milliy-madaniy meros' (Beşik ulusal-kültürel miras), karnay-surnay sadolari (Özbek ulusal üflemeli çalgıların sesleri), ko'rmana (bebek ilk görüldüğünde verilen para veya hediye), milliy marosim (ulusal tören), beshikketti (beşik kertmesi), sarpo qilish (dügüülerde hediye edilen elbiseler takımı) vb.

Ekonomiye ait bilimler pul (para), bozorda sotish (pazarda satış), ko'rmana (bebeğin ilk görüldügünde verilen para veya hediye), sarpo qilish (dügünlerde hediye edilen elbiseler takımı), tog'ora (düğünlerde misafirlere ikram edilen yemekler) gibi çağrışımlarda ifade edilmiştir.

Sanat alanı ile ilişkin bilimler alla (ninni), 'Alla aytay, jonim bolam, orom olgin, alla, Onajoning jonidirsan, qo'zichog'im, alla’ (ninni parçası), karnay-surnay sadolari (Özbek ulusal üflemeli çalgıların sesleri), kuy (müzik), san'at (sanat), Hali hamon ko'z oldimda (hâlâ şimdi göz önümde [şarkı parçası]) çağrışımlarında yansımıştır.

Tip alanı ile ilgili çă̆rışımlar genelde bebeğin sağlığı için beşiğin önemine aittir: juda foydali (sağlık için çok faydalı), oyoq-qo'llarning tog'ri bo'lishi (ayak-ellerin düzgün olması), bolaning orom olishi va tinchlanishi (çocuğun sakinleşmesi ve dinlenmesi), bolaning tinch uxlashi (çocuğun sakin uyuması), Gigienik toza materiallardan tayyorlangan (hijenik, sıhhi malzemelerden yapılmış), parhez (perhiz/diyet), beshikso'poq (beşikte çok yattığından düz kafalılık), shifokorlar (doktorlar).

Sonuç olarak, 'beshik' sözcüğünün çağrışım alanının çözümlenmesi sonucunda çağrışımlar için ortak olan aşağıdaki en mühim nitelikleri tespit edebiliriz: çağrışım birimleri özel sözcük-anlamsal, dil bilgisel, türevsel, biçemsel özelliklere sahiptir; ana dili konuşurunun gerçek dünyaya olan ilişkisini ifade etmek için geniş ölçüde kullanılır; kullanımında cinsiyet özelliğini gösterir, ulusal-kültürel, toplumsal belirtilere malik olur, çeşitli konuşmacılar tarafından istifade edilmesine göre farklı şekillerda kullanılır.

Çağrışım alanı dürtü kelime olan sözcüğün anlam özelliklerinin irdelemesi de çok önemlidir. Çağrışım alanı dürtü kelimenin sözcüksel anlamı, söz- 
lüklerde tespit edilmemiş kimi metinsel, biçemsel, edimsel, lehçe ile ilgili anlamları, söylem kullanımındaki nitelikleri, yan anlamlarını belirtmeye yardım eder.

\section{Sonuç}

Bugün çağrışım dilbilimi, ruhbilimsel-dilbilimin ayrı bir dalı olarak gelişmektedir. Çağrışım dilbilimi özgün inceleme hedefi ve yöntemleri mevcut olan, belli işlevleri amaçlayan bağımsız disiplin olup çeşitli dillerin geniş ölçekli çağrışım sözlüklerinin yaratılması için temel atmaktadır.

Çağrışım dilbilimin irdeleme objesi çağrışımlı düşünüş ürünü olan çağrışımlardır. Çağrışım dilbilimin bilimsel-kuramsal temelini çağrışım ilişkisi teorisi teşekkül eder. Çağrışım ilişkisi, dil birimlerinin insanın psikolojik düşünmesine dayanan 'birbirini hatırlatma’ mekanizmasıdır. Bu ilişki tabanında 'çağrışım' kavramı yatar.

Çağrışım dilbilimde çağrışıım alanı terimi dikkati çekmektedir. Çağrışım alanı, insan bilincinde inikâs eden belli bir gerçek dünya ve onun imgelerinin sözlü ifadesidir. Çağrışım alanı, insan bilgilerini gösterici dilin çağrışımla intisap eden anlamsal ve dil bilgisel birimleri toplamıdır.

Çağrışım alanına birbiriyle anlamsal bağlanan birimlerle birlikte anlamsal olarak intisap etmeyen, ana dili konuşurlarının ruhu, dünya görüşü, ilgileri, âlem hakkındaki bilgileri ile ilgili şekilde hafızasında canlanan birimleri kapsar. Böyle birimler insan bilincinde bir kalıp şeklinde mevcut olan dil birimleri (sözcükler, deyimler, atasözleri, cümleler)dir.

Ruhbilimsel dilbilimde çeşitli dillerdeki sözcüklerin ulusal-kültürel, içtimâ̂, cinsiyet özelliklerini irdelemede çağrışım deneyimler önem taşımaktadır. Çağrışım deneyim yöntemi yardımıyla belli bir halkın ulusal-kültürel haritasını yaratmak olanağı ortaya çıkacaktır. Çağrışım anketleri, çağrışım sözlüklerini oluşturmak için esas kaynak olur.

Çağrışımların meydana gelmesine çeşitli faktörler etki göstermektedir. Herhangi bir sözcüksel birimin anlamı insan hafızasında saklanan farklı düşüncelere ilişik olarak bazı kelimeleri, tamlamaları veya cümleleri hatırlatır, onlarla çağrışımlı bağlanır.

Dilbiliminde sözlü çağrışımlar çeşitli açılardan sınıflandırılır. Sözlü çağrı- 
şımları, oluşması bakımından dilsel ve dil dışı etkenlerle ilgili olarak incelemek mümkündür. Gerçekleştirilen çağrışım anketi sonuçlarına göre Özbek Türkçesindeki sözcüksel çağrışımların aşağıdaki dilsel etkenlerle ilişik tarzda meydana geldiği tespit edildi:

1. Sözcüklerin anlamsal bakımdan birbiriyle ilgili olduğu.

2. Sözcüklerin sözcüksel-dil bilgisel açıdan ilgisi.

3. Sözcüklerin biçemsel bakımından birbirine bağlantı kurduğu.

4. Sözcüklerin edimsel ortaklığı.

5. Sözcüklerin türetilmesindeki benzerlik.

6. Sözcüklerin telaffuzundaki uyum.

7. Sözcüklerin lehçeyle ilgisi.

8. Sözcüklerin ulusal-kültürel birliği.

9. Sözcüklerin toplumsal niteliğine göre yakınlık.

10. Sözcüklerin cinsiyetle alakası.

Özbek Türkçesinde sözlü çağrışımların oluşmasında aşağıdaki dil dışı etkenler önemlidir:

1. Nesnelerin mekânla irtibatı.

2. Nesnelerin zamanla ilişkisi.

3. Nesne ve onun özelliği arasındaki bağlantı.

4. Ses ve ses sahibi ilişkisi.

5. İnsanın gerçekliğe olan münasebeti.

6. Etkinlik ve onun objesi arasındaki ilişki.

7. Etkinlik sahibi ve onun ürünü arasındaki ilişki.

8. Nesnelerin benzerlik belirtisi.

9. Nesnelerin mensupluk, aitlik niteliği.

10. Nesnelerin arasındaki sebep sonuç bağlantısı.

11. Nesnelerin hayati gereksinim işareti.

Çağrışım dilbilimin odak kavramlarından biri sözlü çağrışımdır. Sözlü çağrışım, ana dili konuşurusunun gerçek dünya hakkındaki ruhbilimsel algı- 
sına göre meydana gelir, ama bu düşünüş dilde birbiriyle belli bir açıdan bağlantı kuran belli dilsel birimler vesilesiyle gerçekleşir. Sözlü çağrışımlar her ana dili konuşurunda çeşitli şekilde biçimlenir. Onların kapsamları ana dili konuşurunun sözvarlığını ilgilendirir. Çocuklar ve yetişkinler, kadınlar ve erkeklerle değişik meslek sahiplerinde çağrışım alanı ölçüsü ve terkibi farklı olur. Sözlü çağrışımlar çeşitli konuşma modellerinin oluşmasına imkân sağlar. Çağrışımlı birimler (sözcüksel, sözdizimsel birimler) herhangi konuşma kalıbı için örnek birim işlevini yapar. Dürtü kelime + tepki yanıt modelindeki çağrışım yapısı belli bir durum ifadesine hizmet edebilir.

Çağrışım sözlükleri, birbirleriyle çağrışım bağlantılı sözcükler, onların insan hafızasında biçimlenen 'yuva'ları, çağrışım birimlerinin sözcük-anlamsal, kültürel dilbilimsel, sosyal-dilbilimsel, edimsel dilbilimsel, cinsiyet özellikleri hakkında bilgi verici sözlük çeşidi sayılır. Bununla birlikte, sözlükte verilmiş olan çağrışımlarda ana dili konuşurunun dış dünya hakkındaki görüşleri, bilgisi, bakışı, ruhu, gerçeklikle ilişkisi, hayat deneyleri, fikir-düşünceleri, sorunları yansır. Bu yüzden böyle sözlükler, sadece dilbilim adamları için değil belki tüm kitle için çok önemli bilgi ve veri tabanı işlevini yapar.

\section{Açıklamalar}

1 Ankette çağrışımları oluşturmak için seçilen kelimeler.

2 Örnekler Prof. Dr. D. Lutfullayeva’nın Assosiativ tilshunoslik kitabından alındi.

\section{Kaynaklar}

Abramov, Valeriy Petrovich. Teoriya Assotsiativnogo Polya. Akad. Ped. İ. Sots. Nauk RF, 2003.

Abramova, Yekaterina. "Assotsiativno-Smıslovoe Pole Kontsepta." Apriori. Seriya: Gumanitarnee Nauki, no. 1, 2014, pp. 2-6.

Alefirenko, Nikolay. Souremennıe Problemı Nauki o Yazıke. Flinta, 2005.

Begmatov, Ernest. O'zbek İsmlarining Mảnolari. O'zbek Miiliy Ensiklopediyasi, 2006.

Belyanin, Valeriy. Psiholingvistika. Flinta, 2003.

Belyanin, Valeriy. Uchebnoe Posobie Po Kursu "Psiholingvistika". Noviy Gumanitarnı Universitet Natali Nesterovoy, 1999.

Bolotnova, Nina. "Ob Izuchenii Assotsiativno-Smıslovih Poley Slov v Hudojestvennom Tekste." Rusistika: lingvisticheskaya paradigma kontsa XX veka, 1998, pp. 242-247. 
Volkov, Vadim. Vvedenie v psiholingvistiku. Ujgorodskiy Universitet, 1994.

Goroshko, Yelena. Yazıkovoe Soznanie (Assotsiativnaya Paradigma). IYa RAN INJEK, 2003.

Dimitryuk, Natalya. Kazahsko-Russkiy Assotsiativnıy Slovar. Institut Yazikoznaniya RAN, 1998.

Hojiyev, Azim, and Abdulhamid Nurmonov. Zamonaviy O'zbek Tili Faol So'zlarining İzohli Lug'ati. Fan, 2001.

Karasik, Vladimir. Yazıkovoy Krug, Lichnost, Kontseptı, Diskurs. Gnozis, 2004.

Karaulov, Yuriy. "Russkiy Assotsiativnıy Slovar Kak Noviy Lingvisticheskiy Istochnik I Instrument Analiza Yazıkovoy Sposobnosti.” Russkiy Assotsiativnıy Slovar, 1.kniga, Nauka, 1994, pp. 3-29.

Kent, Grace Helen, and Aaron Joshua Rosanoff. "A Study of Association In Insanity." American Journal of Insanity, vol. 67, no. 1-2, 1910, pp. 317-390.

Kiss, G. R. Ed. The Associative Thesaurus of English. University of Edinburgh, MRC Speech and Communication Unit., 1972.

Krushevskiy, Nikolay. Ocherki O Yazıke. Nauka, 1885.

Lutfullaeva, Durdona. Assotsiativ Tilshunoslik. Meriyus, 2017.

Mahkamov, Nemat, and Ixtiyor Ermatov. Tilshunoslik Terminlerining İzohli Lug'ati. Fan, 2013.

Mahmudov, Nizomiddin, and Durdona Hudaybergenova. O'zbek Tilidagi Ko'chma Manoli So'zlarning Izohli Lug'ati. Fan, 2014.

Martinoviç, Gennadiy. Verbalnıe Assotsiatsii v Assostsiativnom Eksperimente. Nauka, 1997.

Mirzayev, To'ra vd. 'Alpomish' Dostonining İzohli Lug'ati. Fan, 2013.

Madvaliyev, Abduvahob. Ed. O'zbek Tilining Izohli Lug'ati, 1.jild, O'zbekiston Milliy Entsiklopediyasi, 2006.

Madvaliyev, Abdubahob. Ed. O'zbek Tilining Izohli Lug'ati, 2.jild, O'zbekiston Milliy Entsiklopediyasi, 2006.

Madvaliyev, Abdubahob. Ed. O'zbek Tilining Izohli Lug'ati, 3.jild, O'zbekiston Milliy Entsiklopediyasi, 2006.

Madvaliyev, Abdubahob. Ed. O'zbek Tilining Izohli Lug'ati, 4.jild, O'zbekiston Milliy Entsiklopediyasi, 2008.

Madvaliyev, Abdubahob. Ed. O'zbek Tilining Izohli Lug'ati, 5.jild, O'zbekiston Milliy Entsiklopediyasi, 2008.

Popova, Zinaida, and Iosif Sternin. Kognitivnaya Lingvistika. Vostok-Zapad, 2007. Postman, Leo Joseph, and Geoffrey Keppel. Norms of Word Associations. Acadenic Press, 1970.

Rahmatullayev, Shafkat. O'zbek Tilining Etimologik Lug'ati, 1.jild, Fan, 2000.

Rahmatullayev, Shafkat. O'zbek Tilining Etimologik Lug'ati, 2.jild, Fan, 2003. 
Rahmatullayev, Shafkat. O'zbek Tilining Etimologik Lug'ati, 3.jild, Fan, 2009.

Karaulov, Yuriy. Ed. Russkiy Assotsiativnıy Slovar, 1. tom, Nauka, 1994.

Karaulov, Yuriy. Ed. Russkiy Assotsiativnıy Slovar, 2. tom, Nauka, 1998.

Sanchez, Puig M. vd . Normas asoczativas del espanol y del ruso. Moscu, 2000.

Ufimseva, Natalya. Haz. Slavyanskiy Assotsiativnıy Slovar (Russkiy, Belorusskiy, Bolgarskiy, Ukrainskiy). Institut Yazıkoznaniya RAN, 2004.

Slishkin, Gennadiy. Ot Teksta K Simvolu: Lingvokulturne Kontseptı Pretsedentnıx Tekstov V Soznanii I Diskurse. Academia, 2000.

Titova, Larisa Nikolaevna. Kirgizsko-Russkiy Assotsiativnıy Slovar. Mektep, 1972.

Ulyanov, Yuriy. Latıshsko-Russkiy Assotsiativnyy Slovar. Zinantne, 1988.

Cherkasova, Galina. Russkiy Sopostavitelnıy Assotsiativnıy Slovar. Nauka, 2008.

Zalevskaya, Aleksandra. Vvedenie V Psiholingvistiku. Rossiyskiy Gosudarstvennıy Gumanitarnıy Universitet, 1999. 


\title{
Theoretical and Applied Methods of Creating Associative Dictionary of The Uzbek Language ( $0 n$ the Example of the Word "Beshik")*
}

\section{Zilola Khudaybergenova**}

\begin{abstract}
In the world linguistics of the XXI century, the human factor have became the main subject of language learning, as a result, new directions of linguistics, based on the prism of the triangle "man + culture + language", have appeared. Currently, such areas of linguistics as cultural linguistics, pragmalinguistics, psycholinguistics, cognitive linguistics, sociolinguistics, associative linguistics explore the language taking into account the cognitive, psychological, cultural, national, social characteristics of a person in relationships with history, national traditions, politica, cultural peculiarities of linguistic societies as well as geographic locations of the country. Associative linguistics, deals with associations that arise in the minds of speakers, associated with certain concepts, thereby they become the material for the creation of associative dictionaries. Associative dictionaries of certain languages, published in the twentieth century, were the impetus for the creation of an associative dictionary of the Uzbek language. This article will consider the history of the creation of associative dictionaries, theoretical and practical methods of compiling associative dictionaries, works aimed at creating an Uzbek associative dictionary, methods and principles for studying associations, structure, methods and principles of creating associative dictionaries.
\end{abstract}

\section{Keywords}

Uzbek language, Uzbek associative linguistics, associative dictionaries, method of associative experience, associative units, principles of associative dictionaries.

You can refer to this article as follows:

Khudaybergenova, Zilola. "Theoretical and Applied Methods of Creating Associative Dictionary of The Uzbek Language (On the Example of the Word “Beshik”).” bilig, no. 98, 2021, pp. 75-97.

* Prof.Dr., Bartın University, Faculty of Literature, Department of Contemporary Turkic Dialects and Literature Bölümü - Bartın/Turkey

ORCID: 0000-0003-1021-3053

aloliz74@mail.ru, zkhudaybergenova@bartin.edu.tr 


\title{
Теоретические и прикладные методы создания ассоциативного словаря узбекского языка (на примере слово «бешик»)
}

\section{Зилола Кудайбергенова}

\begin{abstract}
Аннотация
В XXI веке человеческий фактор в мировой лингвистике стал одним из основных тем при изучении языка. В результате возникли новые отрасли лингвистики, основанные на треугольнике «человек + культура + язык». Наряду с этим родились такие лингвистические направления, как лингвокультурология, прагматическая лингвистика, психологическая лингвистика, когнитивная лингвистика, социальная лингвистика, ассоциативная лингвистика. Эти изучают язык учитывая когнитивные, психологические, культурные, национальные и социальные характеристики носителей языка; принимая во внимание исторические, национальные традиции, политические и культурные признаки общего языка общества, а также его взаимодействие с географическими условиями рассматриваемой страны. Ассоциативная лингвистика изучает ассоциации, которые возникают в сознании носителей языка по поводу определённых концепций; из этого и возникла нужда в написании ассоциативных словарей. Изданные в XX веке ассоциативные словари иностранных языков привлекли внимание узбекских учёных, которыми были инициированы работы над составлением ассоциативного словаря узбекского языка. В данной статье будут рассмотрены история, теоретические и практические методы создания ассоциативных словарей, исследования по созданию узбекского ассоциативного словаря, принципы изучения ассоциаций, а также структура этого словаря.
\end{abstract}

\section{Ключевые слова}

Узбекский язык, узбекская ассоциативная лингвистика, ассоциативные словари, метод ассоциативного опыта, ассоциативные единицы, принципы создания ассоциативных словарей.

\footnotetext{
Поступило в редакцию: 26 Январь 2019 г. - Принято в номер: 19 июнь 2019 г.

Ссылка на статью:

Khudaybergenova, Zilola. “ Özbek Türkçesi Dilbiliminde Çağrışım Sözlüğünü Oluşturmanın Kuramsal ve ‘Beşik’ Kelimesi Örneğinde Uygulamalı Yöntemleri.” bilig, no. 98, 2021, pp. 75-97.

** Проф., д-р, Университет Бартин, филологический факультет, кафедра современных тюркских языков и литератур - Бартин / Турция ORCID: 0000-0003-1021-3053 aloliz74@mail.ru, zkhudaybergenova@bartin.edu.tr
} 